\title{
Hallux Valgus and Hammer Toe
}

\author{
Hallux Valgus e Dedo em Martelo
}

Moisés HENRIQUES ${ }^{1,2}$

Acta Med Port 2013 Nov-Dec;26(6):758-758

Keywords: Hallux Valgus; Hammer Toe Syndrome.

Palavras-chave: Hallux Valgus; Síndrome do Dedo do Pé em Martelo.

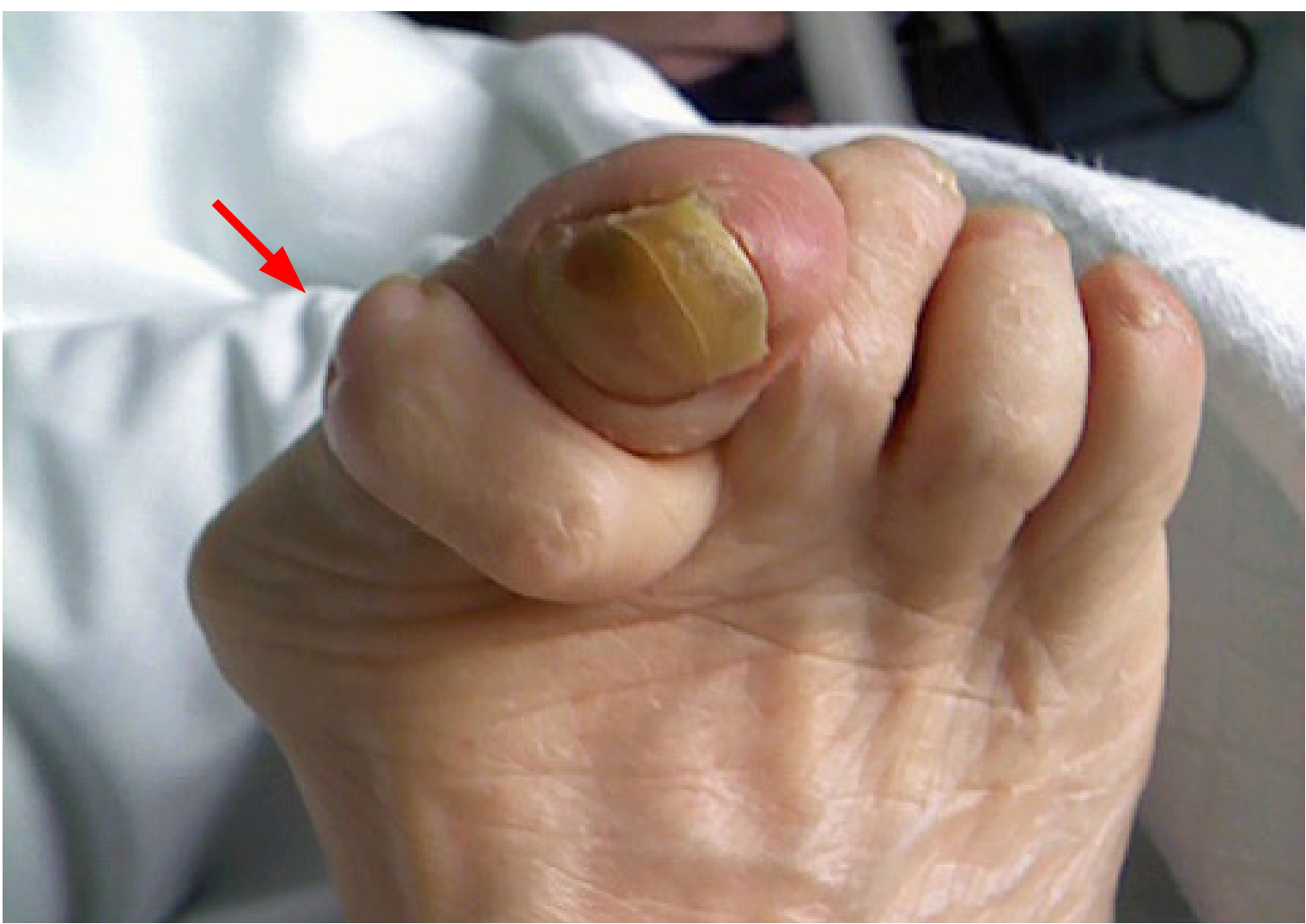

Figure 1 - Hallux Valgus and Hammer Toe.

An elderly woman was observed after hip surgery to start a rehabilitation program; physical examination revealed a lush hallux valgus, however no complaints were reported.

Hallux valgus is a frequent forefoot deformity; global prevalence is $35 \%$ in those over 65 years-old. ${ }^{1}$ Women are more affected; deformity is normally attributed to ill-fitting shoes. ${ }^{1}$ Imbalance of the extrinsic/intrinsic foot muscles and ligaments is involved in pathogenesis. ${ }^{1}$

Symptoms include pain in the bunion, hammer or claw toe, and metatarsalgia. ${ }^{1}$ An angle $\left(>15^{\circ}\right)$ between the longitudinal axes of the first metatarsal and the proximal phalanx of the hallux with the vertex at the head of the first metatarsal confirms the diagnosis. ${ }^{1}$

Adequate correction isn't possible in the elderly and conservative treatment is restricted to symptoms relief. ${ }^{1}$ Surgical treatment is indicated when maintained pain impairs foot function and should be followed by a rehabilitation program, usually with full load bearing in a flat orthopedic shoe. ${ }^{1}$

\section{REFERENCES}

1. Wülker N, Mittag F. The treatment of hallux valgus. Dtsch Arztebl Int. 2012;109:857-68.

1. Gabinete Médico. Centro de Educação Física da Armada. Almada. Portugal.

2. Serviço de Medicina Física e de Reabilitação. Hospital Santa Maria (Centro Hospitalar Lisboa Norte). Lisboa. Portugal.

Recebido: 04 de Julho de 2013 - Aceite: 15 de Agosto de 2013 | Copyright @ Ordem dos Médicos 2013 


\section{Hallux Valgus and Hammer Toe Acta Med Port 2013:26:758-758}

Publicado pela Acta Médica Portuguesa, a Revista Científica da Ordem dos Médicos

Av. Almirante Gago Coutinho, 151

1749-084 Lisboa, Portugal.

Tel: +351218428215

E-mail: submissao@actamedicaportuguesa.com

www.actamedicaportuguesa.com

ISSN:0870-399X | e-ISSN: 1646-0758

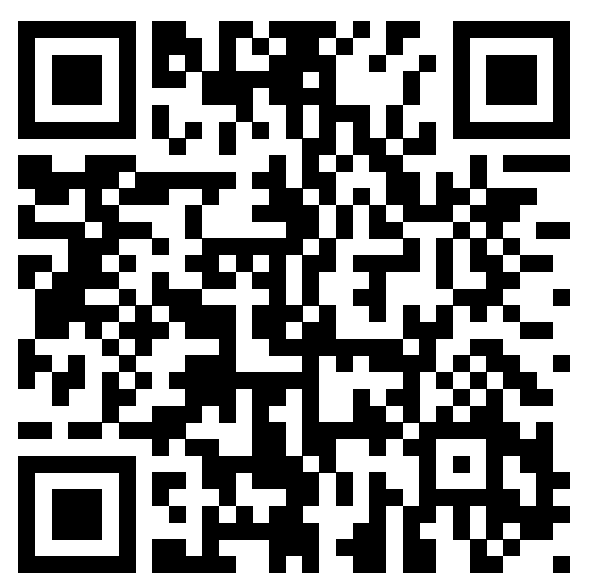

